\title{
RECOVERY OF DEGRADED AREA OF Urochloa decumbens WITH TURKEY LITTER FERTILIZER
}

\author{
RECUPERAÇÃO DE ÁREA DEGRADADA DE Urochloa decumbens ADUBANDO \\ COM CAMA DE PERU
}

\section{Andrisley Joaquim da SILVA ${ }^{1}$; Fernando França da CUNHA ${ }^{2}$; Cassiano Garcia ROQUE ${ }^{3}$; Diego Oliveira RIBEIRO ${ }^{1,4}$; Manuel Rodriguez CARBALLAL ${ }^{1}$; Monice Donatila Tavares da SILVA ${ }^{1}$}

1. Adjunct Professor, University Center of Mineiros, Mineiros, GO, Brazil; 2. Adjunct Professor, Federal University of Viçosa, Viçosa, MG, Brazil. fernando.cunha@ufv.br; 3. Associate Professor, Federal University of Mato Grosso do Sul, Chapadão do Sul, MS, Brazil. 4. PhD student of Agricultural Sciences, Goiano Federal Institute, Rio Verde, GO, Brazil

\begin{abstract}
The aimed of this study was to evaluate the effects of different dosages of turkey litter on soil's chemical attributes and yield of the Urochloa decumbens in classified as degraded pasture. The work was performed at the municipality of Mineiros-GO between October/2011 and September/2013 in Quartzipsamment soil. The treatments consisted in applications of $0,3,6,9$ and $12 \mathrm{Mg} \mathrm{ha}^{-1}$ of turkey litter at a randomized-complete blocks design with four replications. Was evaluated the fodder's productivity and the following soil's chemical attributes: organic matter, hydrogenionic potential $\left(\mathrm{CaCl}_{2}\right)$, phosphorus (resin), potassium, calcium, magnesium, cation exchange capacity and base saturation of soil. In general terms, the increase of turkey litter's doses increased the grass productivity and the supply of nutrients of the soil, maintaining the balance of the soil-plant system. The dosage of $12 \mathrm{Mg} \mathrm{ha}^{-1}$ year $^{-1}$ of turkey litter ensure higher amounts in the soil's chemical attributes and in the productivity of dry mass of Urochloa decumbens.
\end{abstract}

KEYWORDS: Brachiaria grass. Organic fertilization. Poultry litter. Soil fertility.

\section{INTRODUCTION}

The usage of grazing for ruminant production is the most economically practicable ways of providing the herd's sustenance, since it reduces the cost of production, being the best alternative to competitive and sustainable animal production (ALENCAR et al., 2009; 2014).

Even being the species of Urochloa welltolerating to the specific soil and climate conditions of the Cerrado, the improper management and the lack of corrective fertilization at the establishing and of maintenance fertilization for replacing the soil's nutrients contribute to the damage of the areas with cultivated pasture (CASTRO et al., 2012). This way, these areas tends to present lower tolerance to water stress, emphasizing the effects of weather extremes above the pasture development and growing (BONFIM-SILVA et al., 2011).

The management of the soil's fertility of fields with degraded pasture differs from the ones held in recently developed areas, or on those worked extensively for many years, with the response to the usage of fertilizers in degraded pasture rising during the recovery process (FOGEL et al., 2013), being necessary the use of high dosages of fertilizers. Thus, the usage of alternative products, with low cost, might be a great alternative for decapitalized properties.

The application of residues in agricultural practices has been showing that its disposal in the ground brings a series of elements that might change its physical, chemical and, mostly, in its biological attributes (LANA et al., 2010; CONTE et al., 2011; FAVARATO et al., 2015; OLIVEIRA et al., 2016). Thus, its application can affect the balance of the soil-plant system. The changes will benefit the plant if the residues are applied in the right amount, way and frequency, otherwise the system might present adverse environmental impact (RAMOS et al., 2017).

Other benefits provided by the usage of wastes such as compost are the increase of the amounts of phosphorus and potassium in the soil, dry matter increase, of the levels of foliar phosphorus and of the crude protein (PINTO et al., 2012; SILVA et al., 2012; SILVA et al., 2014; SILVEIRA JÚNIOR et al., 2015). According to Fogel et al. (2013), amongst the existing residues, the poultry litter stands out mainly for its economical factor (low-cost by tons), besides the easily for acquisition. This material comes from poultry installations, in which the excrements, feed leftovers and feathers accumulate through the poultry's growth, what makes the material rich in 
nutrients. Its reusage is a viable alternative to reduce the gathering of this residue at the installations, what makes this material a promising fertilization source.

Findings of Valadão et al. (2011) showed that non-composted poultry litter increases the soil's total nitrogen levels, while the composted litter offers the ground higher amounts of total carbon and physical attributes similar to those of a native vegetation environment. Silva et al. (2011) related that the appliance of arising dosages of poultry litter helps at the rising of the copper absorption and in the reduction of manganese, besides increasing the iron levels of the plant.

Considering the possibility of turkey litter as fertilizer at the recovery of pasture the goal of the present study was to evaluate the effects of different dosages of poultry litter, specifically turkey, at the chemical attributes of the soil and at the productivity of dry mass of degraded Urochloa decumbens pasture.

\section{MATERIAL AND METHODS}

The experiment was carried out at the Experimental Farm Prof. Dr. Luiz Eduardo de Oliveira Sales, belong to the Centro Universitário de Mineiros (UNIFIMES), located under the coordinates $17^{\circ} 27^{\prime} 16.14$ ' $\mathrm{S}, 52^{\circ} 36^{\prime} 9.85^{\prime}$ ' W with an average altitude of $850 \mathrm{~m}$ above the sea level, at the municipality of Mineiros, Goiás State, Brazil.

The experiment extents for two years, being the first year of evaluation performed between October/2011 and September/2012, and the second year between October/2012 and September/2013.

The area has a pasture of degraded Urochloa decumbens Stapf, with an average stocking rate of $0.4 \mathrm{UA} \mathrm{ha}^{-1}$ (UA = animal unit of $450 \mathrm{~kg}$ ). The pasture had been formed about 15 years before and does not had none properly soil fertility management until the beginning of this study.

The area's soil is labeled as Quartzipsamment soil (EMBRAPA, 2013), average texture of $15 \%$ of clay. The chemical attributes of the soil were determined at the Soil's Laboratory of the UNIFIMES of Mineiros-GO (Table 1).

Table 1. Results of the chemical analysis of the layer $0-0.20 \mathrm{~m}$ of the soil in the experimental area. MineirosGO, UNIFIMES, 2011

\begin{tabular}{|c|c|c|c|c|c|c|c|c|c|}
\hline $\mathrm{pH}$ & $\underset{\mathrm{OM}}{\mathrm{OM}}$ & $\mathrm{P} \underset{\mathrm{No}}{\mathrm{K}}$ & $\mathrm{Ca}$ & $\mathrm{Mg}$ & $\mathrm{Al}$ & $\mathrm{H}+\mathrm{Al}$ & SB & CEC & V \\
\hline 4.7 & 11.0 & 1.0 & 5.0 & 2.0 & 1.0 & 18.0 & 7.2 & 25.2 & 28.7 \\
\hline
\end{tabular}

According to Köppen's climatic classification (ALVARES et al., 2013), the climate of the region is Aw, humid tropical, typified by two well marked seasons: a dry one, corresponding to the period amid May and September; and the other humid, corresponding to the period amid October and April. The average annual rainfall is $1,350 \mathrm{~mm}$ and the average annual temperature is $22.5{ }^{\circ} \mathrm{C}$ (INMET, 2019). The daily average of temperature and daily variation of rainfall over the experimental period was obtained from the automatic meteorological station located at the UNIFIMES' campus (Figure 1).

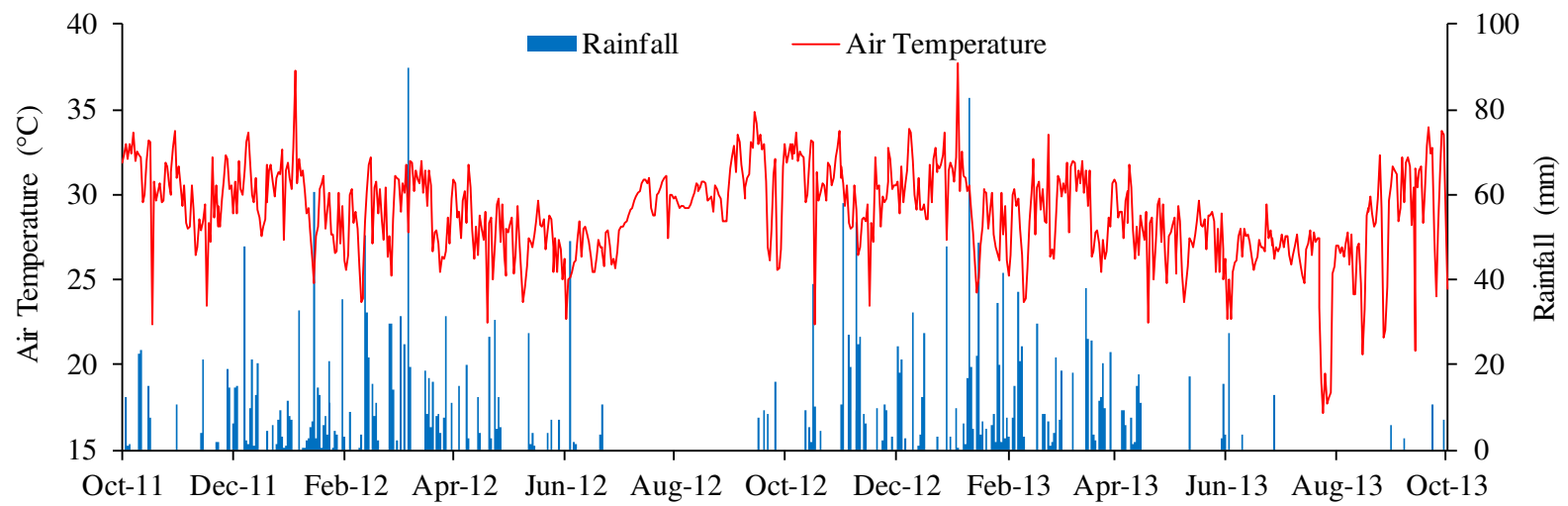

Figure 1. Daily variations of the air temperature $\left({ }^{\circ} \mathrm{C}\right)$ and rainfall $(\mathrm{mm})$. Mineiros-GO, UNIFIMES, 2011-2013. 
The experiment presented five treatments with different dosages of turkey litter, analyzed in two agricultural years as a randomized-complete blocks design with four replications. The treatments consisted in applications of different levels of fertilization, with turkey litter, at the degraded pasture of Urochloa decumbens (Table 2). The experimental plots were composed of areas of $4 \mathrm{~m}^{2}$, with dimensions of $2.0 \mathrm{~m}$ of length by $2.0 \mathrm{~m}$ in width.

Table 2. Quantification of macronutrients for the different dosages of turkey litter used in the fertilization of degraded pasture of Urochloa decumbens. Mineiros-GO, UNIFIMES, 2011-2013

\begin{tabular}{ccccc}
\hline \multirow{2}{*}{ Treatments } & $\begin{array}{c}\text { Dosage } \\
\left(\mathrm{Mg} \mathrm{há}^{-1}\right)\end{array}$ & $\mathrm{N}$ & $\mathrm{P}_{2} \mathrm{O}_{5}$ & $\mathrm{~K}_{2} \mathrm{O}$ \\
\cline { 2 - 5 } & 0 & 0 & 0 & 0 \\
Control & 3 & 85.2 & 106.5 & 74.5 \\
Turkey Litter & 6 & 170.4 & 213.0 & 149.0 \\
Turkey Litter & 9 & 225.6 & 319.5 & 223.5 \\
Turkey Litter & 12 & 340.8 & 426.0 & 298.0 \\
Turkey Litter & & &
\end{tabular}

The application of the fertilization treatments to the soil were performed in October of 2011 and October of 2012. The Comissão de Fertilidade do Solo (1995) suggested indices of efficiency at the release of nutrients from the organic form to the mineral form. The Nitrogen present availability of $50 \%$ immediately and the remainder gradually. In the same way, the $\mathrm{P}_{2} \mathrm{O}_{5}$ provides $50 \%$ immediately and the remainder gradually. The $\mathrm{K}_{2} \mathrm{O}$ has prompt release. The chemical evaluation of the original material of turkey litter used in the present experiment is presented in the Table 3.

Table 3. Levels of nutrients in the turkey litter used in the fertilization of the pasture. Mineiros-GO, UNIFIMES, 2011

\begin{tabular}{ccccccc}
\hline $\mathrm{N}$ & $\mathrm{P}_{2} \mathrm{O}_{5}$ & $\mathrm{~K}_{2} \mathrm{O}$ & $\mathrm{Ca}$ & $\mathrm{Mg}$ & $\mathrm{S}$ & Humidity \\
\hline 4.0 & 5.0 & 3.5 & 3.2 & 0.46 & 0.2 & 29.0 \\
\hline
\end{tabular}

Source: Laboratório Exata, Jataí-GO, 2011.

The turkey litter was manually distributed on the deployment day of the experiment. After the application, the cuts began, always respecting the height of the entrance of $0.30 \mathrm{~m}$ and exit of $0.15 \mathrm{~m}$ of pasture forage.

The acquisition of the grass dry mass yield was made manually, in an area delimited by a metallic sampling unit, of rectangular shape with sides of $1.0 \times 1.0 \mathrm{~m}\left(1.0 \mathrm{~m}^{2}\right)$. The sampling unit was positioned in predetermined places, avoiding the collection of successive samples in the same spot. All the green mass harvested was secured in plastic bags, previously identified and immediately weighted. Subsequently a subsample was removed, also weighted, secured in an identified paper bag and placed to dry at a conservatory with air circulation at $65{ }^{\circ} \mathrm{C}$, for a period of 72 hours. After the drying, the subsamples were weighted again for the obtaining of the level of dry mass and afterwards the productivity of dry mass.

After each cut, the remainder amount of the experimental unit was chopped with a costal lawn mower for homogenization. The rest of the material produced by the cutting was removed from the experimental area in a way they wouldn't interfere in the subsequent evaluations.

For the soil data acquisition was collected after the last cut (October 2013) in the layer of 0$0.20 \mathrm{~m}$, removing 6 subsamples for the establishment of a composed sample for each replication. The soil samples were then taken to be processed in the Soil's Chemical Laboratory of the Centro Universitário de Mineiros (UNIFIMES). Once the samples were received at the lab, they were exposed to dry in the shadow and, posteriorly, sieved in a sieve with an opening of $2.0 \mathrm{~mm}$, for separating the thicker particles. The thin earth dried in the air, caused by these procedures, was stored for later analysis.

The parameters obtained and calculated were: organic matter, hydrogenionic potential (in $\mathrm{CaCl}_{2}$ ), phosphorus (resin), potassium, calcium, magnesium, cation exchange capacity and base saturation of soil.

The data were submitted to the regression analysis. The tested models were first and second 
degrees polynomials, chosen by the significance of its regression coefficients, employing the test $t$ at 0.05 of probability, at the coefficient of determination $\left(\mathrm{R}^{2}\right)$ and at the biological phenomenon. The software "SigmaPlot 11.0" (SYSTAT SOFTWARE, INC., 2011) was employed to perform the statistical analysis.

\section{RESULTS AND DISCUSSION}

The application of growing dosages of turkey litter provided a quadratic effect in the productivity of dry mass (DM) of the Urochloa decumbens in the two agricultural years evaluated. The dosages of turkey litter that maximized the productivity of DM of Urochloa decumbens were 12.0 and $11.1 \mathrm{Mg} \mathrm{ha}^{-1} \mathrm{year}^{-1}$, resulting in the productivity of DM of 26.5 and $9.6 \mathrm{Mg} \mathrm{ha}^{-1}$ year $^{-1}$ for the agricultural years 1 and 2, respectively. Silva et al. (2014) applied biofertilizers of poultry waste in Urochloa brizantha, in Aquidauana-MS, and also verified a rising of the productivity of DM at the cultivation Piatã e Marandu until a maximum dosage, after that there's a decline in the productivity.
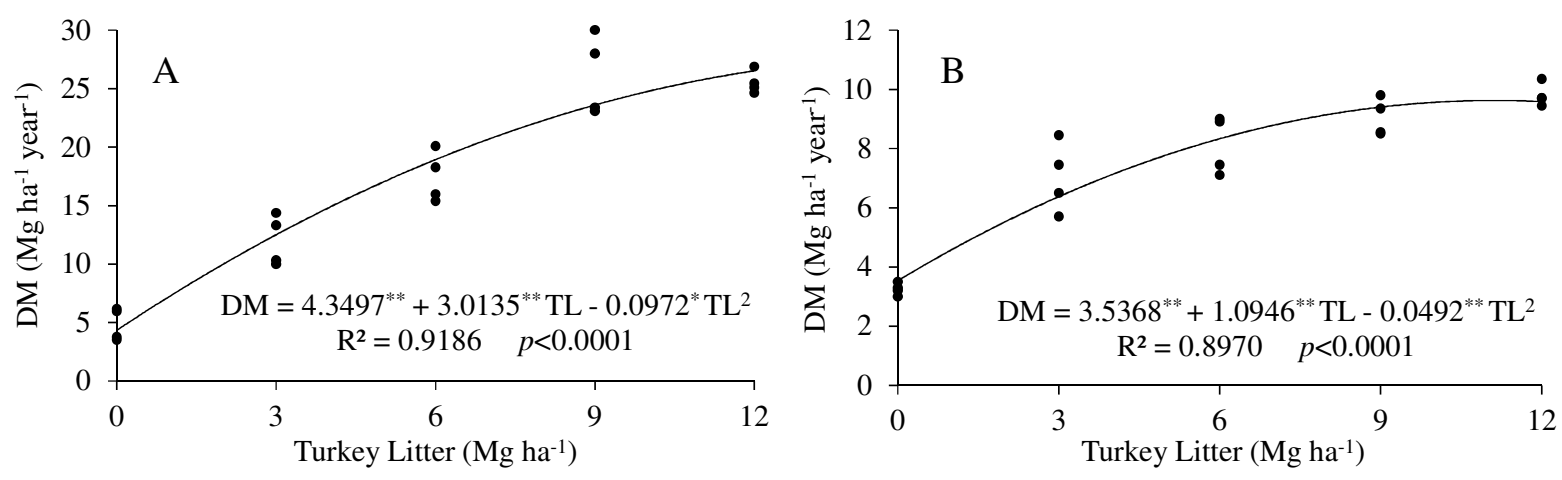

* and * meaning at 1 and $5 \%$ of probability, respectively.

Figure 2. Estimation of the productivity of dry mass (DM) of the Urochloa decumbens submitted to different dosages of the turkey litter (TL), at (A) first and (B) second agricultural year. Mineiros-GO.

The initial increase in the productivity of DM with small dosages of turkey was mostly due to the input of macro and micronutrients to the soil. Pinto et al. (2012), performing sequential applications of turkey litter in soil cultivated with Urochloa decumbens, verified improvements in the soil's fertility, with an increase of the $\mathrm{pH}$, phosphorus, potassium and base saturation, and a decrease in saturation by aluminum. These authors also checked that rising dosages of turkey litter benefited the increase in the levels of the storage of organic carbon, total nitrogen and particulate nitrogen. The application of smaller dosages of turkey litter stimulated the microbial activity in the soil, promoting the mineralization of the particulate fraction of the organic matter.

Analyzing the regression equations of the Figure 2, it is visible in the higher dosages of turkey litter a declining tendency in the DM's productivity of Urochloa decumbens. Probably, this behavior might be due to the nutritional demands of the pasture having been already attended or exceeded, and/or due to problems in the soil's structure. It is known that high doses of organic material, when applied to the soil, cause it's destructuring, mainly because of the unbalance between salts mono in relation with the bi and trivalent, causing clay dispersion and reducing the capacity of water infiltration and gas entrance at the soil. Silva et al. (2014) verified in their experiment the death of the grass Piatã e Marandu due to the excess application of organic material. According to these authors, the death of the plants was on the account of the excess of nitrogen existent in the organic fertilizer. Silva et al. (2014) state that the elevated levels of nitrogen in poultry biofertilizer might have a toxic effect above a certain culture, being important to evaluate its dosages in order to provide a safe recommendation for the producing of forage.

Based on the above considerations, with the knowledge that there will be a dosage of turkey litter that will maximize the productivity of the DM of Urochloa, it is believed that this will be superior than $12 \mathrm{Mg} \mathrm{ha}^{-1}$ year $^{-1}$. Therefore, it is suitable making other studies to determine this maximum dosage.

When applying different dosages of poultry litter in the Urochloa brizantha in the Zona da Mata 
of Rondônia, Lara et al. (2015) verified that the maximum productivity of DM was reached with the dosage of $80 \mathrm{Mg} \mathrm{ha}^{-1}$ year-1 $^{-1}$ Orrico Júnior et al. (2013), using different dosages of organic compound at the Piatã grass, in the city of Dourados-MS, concluded that the productive, morphogenetic and structural characteristics of the plant responded incrementally until the dosage of $0.3 \mathrm{Mg} \mathrm{ha}^{-1}$ year $^{-1}$ of $\mathrm{N}$, regardless the used source, that was, in this case, compounds originating from broiler litter based on sugar cane and the Pennisetum purpureum grass.

It is noticeable that the productivity of DM of Urochloa decumbens reduced from the first to the second agricultural year (Figure 2). This might indicate the possibility of strategical use of this source every two years in already established pasture. On the other hand, perhaps this shows that the applied dosage of nutrients in the treatments was not enough to guarantee good productivity in the second year, being necessary the making of other studies to give more details on this question. Fogel et al. (2013) relate that recovering degraded grass demands high levels of nutrients to keep the system in balance. Euclides et al. (2007) also stated a decrease in the productivity of DM. These authors applied $200 \mathrm{~kg} \mathrm{ha}^{-1}$ of the formula NPK of $0-20-20$ and, annually, in the time of the deferral of the pasture, were applied $110 \mathrm{~kg} \mathrm{ha}^{-1}$ of coverage urea. The authors observed maximal productivities of DM of $4.6 \mathrm{Mg} \mathrm{ha}^{-1}$ year $^{-1}$ fall to $3.7 \mathrm{Mg} \mathrm{ha}^{-1}$ year $^{-1}$ in the second agricultural year.

The dosages of turkey litter provided a quadratic effect on the soil's organic matter (Figure 3 A), cultivated with Urochloa decumbens. According to the regression equation, the dosage of turkey litter that maximized the soil's organic matter was of $7.9 \mathrm{Mg} \mathrm{ha}^{-1}$ year-1, resulting in the level of $28.0 \mathrm{~g} \mathrm{dm}^{-3}$. Compared with the beginning of the experimental process, the increase of organic matter enabled by the turkey litter to the soil was of $17.0 \mathrm{~g}$ $\mathrm{dm}^{-3}(155 \%)$.

The highest dosages of turkey litter leaded to a decline in the organic matter, probably due to the increase of the grass production, contributing to the increment of the carbon in the particulate fraction, as mentioned by Pinto et al. (2012). The application of the turkey litter probably stimulated the decomposition of the particulate fraction of the organic matter, reducing its supply. Since this fraction is taken as more labile (CONTE et al., 2011), it serves as a fount of carbon to the soil microbiota, with the process being accelerated by the inclusion of $\mathrm{N}$ and $\mathrm{P}$ provided by the turkey litter, helping the decomposition of such fraction.
This reduction might relate to the long periods between the applications. However, according to Pinto et al. (2012), the storage tends to recover with time and the application of poultry litter, which promote the forage growth.

The results obtained for the organic matter reinforce the concerns some authors have regarding the excessive application of residues damaging the soil and/or the development/growing of the forage plants. Fogel et al. (2013) states that the knowledge about the benefits of the application of poultry litter by the producers can, occasionally, cause excess in the used dosages, mostly in the first years using this way of fertilization, what leads to negative effects on the environment. These authors also report the need to evaluate the effects of the excess of fertilization from this source above the environmental conditions, especially regarding the nitrate leaching.

The dosage of turkey litter provided a quadratic effect in the cation exchange capacity (CEC) of the soil cultivated with Urochloa decumbens (Figure 3G). According to the regression equation, the dosage of turkey litter which maximized the CEC was of $9.3 \mathrm{Mg} \mathrm{ha}^{-1}$ year $^{-1}$, resulting in the value of $44.7 \mathrm{mmol}_{\mathrm{c}} \mathrm{dm}^{-3}$. This effect might be assigned to the behavior observed in the organic matter. Signor et al. (2016) state that up to $90 \%$ of the CEC of the soil in tropical weather comes from the organic matter, highlighting the data obtained in this study.

The results of this research support the ones obtained by Favarato et al. (2015). These authors added organic compounds to the soil and checked a rising in its $\mathrm{OM}$ and, indirectly, also observed an increment in the levels of the soil's effective and total CEC, provided a higher number of sites with negative charges, favoring the adsorption of $\mathrm{H}^{+}$ions. Ciotta et al. (2003) observed that even not very significant increases of $\mathrm{OM}$ can provide elevate results in the increments of the soil's CEC, being possible to achieve increases of even $87 \%$ during 21 years of direct planting.

The soil's chemical attributes hydrogenionic potential, phosphorus, potassium, calcium and magnesium responded in an incrementally linear way to the rising in the turkey litter dosages (Figure $3 \mathrm{~B}, 3 \mathrm{C}, 3 \mathrm{D}, 3 \mathrm{E}$ e $3 \mathrm{~F}$ ). This result is due to the presence of such elements in the turkey litter. Pinto et al. (2012) performing sequential applications of turkey litter in soil planted with Urochloa decumbens, checked improvements in the soil's fertility, with an increase in the $\mathrm{pH}$, phosphorus, potassium and base saturation, and a decrease in saturation by aluminum. In the same way, Silveira 
Júnior et al. (2015), working with Urochloa brizantha cv. Piatã, in Araguaína-TO, also checked a rising in the levels of organic matter, $\mathrm{pH}$, phosphorus, potassium, calcium, magnesium, CEC and base saturation in the layer $0-0.15 \mathrm{~m}$ from the soil in function of the rising in the dosages of biofertilizer poultry litter.
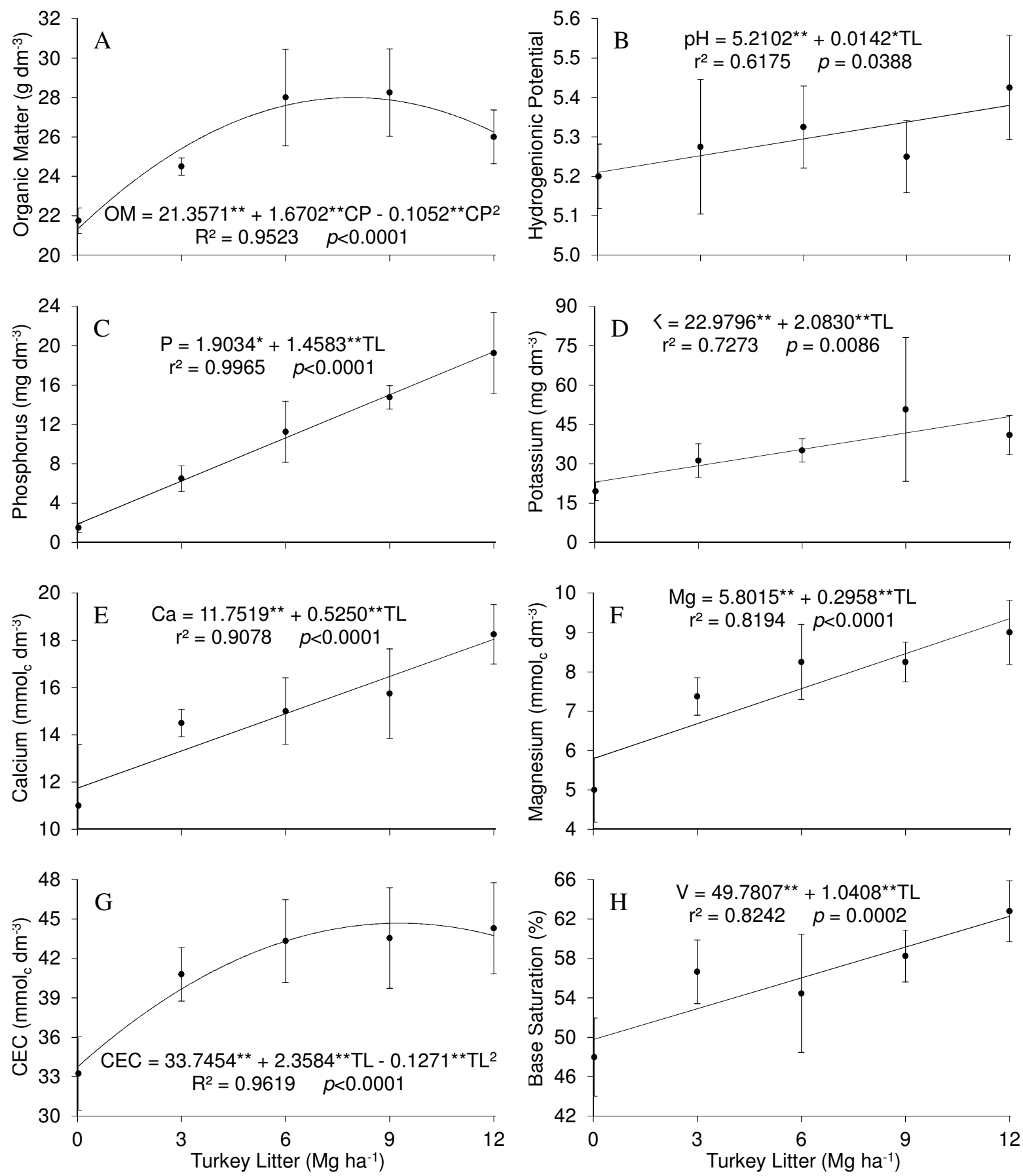

** and * meaning at 1 and $5 \%$ of probability, respectively.

Figure 3. Average values of (A) organic matter, (B) hydrogenionic potential, (C) phosphorus, (D) potassium, (E) calcium, $(\mathrm{F})$ magnesium, $(\mathrm{G})$ cation exchange capacity and $(\mathrm{H})$ base saturation at the soil layer of $0-0.20 \mathrm{~m}$ according to the dosages of turkey litter (TL) over two agricultural years. Mineiros-GO, UNIFIMES, 2011-2013. 


\section{CONCLUSIONS}

The usage of turkey litter until the dosage of $12 \mathrm{Mg} \mathrm{ha} \mathrm{year}^{-1}$ for two consecutive years promotes an increase of the $\mathrm{pH}$ and organic matter, levels of $\mathrm{P}, \mathrm{K}, \mathrm{Ca}$ and $\mathrm{Mg}$, besides that, it's also contributed for increase of the CEC and the V\% of the soil, maintaining the balance of the soil-plant system.

The dosage of $12 \mathrm{Mg} \mathrm{ha}^{-1}$ year ${ }^{-1}$ from turkey litter provides an increase in the production of forage in degraded pasture of Urochloa decumbens.

RESUMO: Objetivou-se avaliar os efeitos de diferentes doses de cama de peru nos atributos químicos do solo e na produtividade de pastagem degradada de Urochloa decumbens. O experimento foi conduzido no município de Mineiros, GO entre outubro/2011 a setembro/2013 em Neossolo Quartzarênico Órtico. Os tratamentos foram constituídos de aplicações de 0, 3, 6, 9 e $12 \mathrm{Mg} \mathrm{ha}^{-1}$ de cama de peru, no delineamento em blocos casualizados com quatro repetições. Foram avaliadas a produtividade de forragem e os atributos químicos do solo: matéria orgânica, potencial hidrogeniônico $\left(\mathrm{CaCl}_{2}\right)$, fósforo (Resina), potássio, cálcio, magnésio, capacidade de troca catiônica e saturação por bases do solo. Em termos gerais, o aumento das doses de cama de peru proporcionou acréscimos na produtividade de capim e no aporte de nutrientes no solo, mantendo o equilíbrio do sistema solo-planta. Concluiu-se que a dose de $12 \mathrm{Mg} \mathrm{ha}^{-1}$ ano $^{-1}$ de cama de peru garante maiores valores dos atributos químicos do solo e produtividade de massa seca da Urochloa decumbens.

PALAVRAS-CHAVE: Adubação orgânica. Cama aviária. Capim-braquiária. Fertilidade de solos.

\section{REFERENCES}

ALENCAR, C. A. B.; CUNHA, F. F.; OLIVEIRA, R. A.; CÓSER, A. C.; MARTINS, C. E. Effect of irrigation and annual seasons on the chemical composition and digestibility of grasses under grazing. Engenharia na Agricultura, Viçosa, v. 22, n. 4, p. 331-340, 2014. http://doi.org/10.13083/1414-3984.v22n04a05

ALENCAR, C. A. B.; OLIVEIRA, R. A.; CÓSER, A. C.; MARTINS, C. E.; CUNHA, F. F.; FIGUEIREDO, J. L. A.; LEAL, B. G.; CECON, P. R. Cobertura do solo e altura de capins cultivados sob pastejo com distintas lâminas de irrigação e estações anuais. Bioscience Journal, Uberlândia, v. 25, n. 1, p. 113-121, 2009.

ALVARES, C. A.; STAPE, J. L.; SENTELHAS, P. C.; GONÇALVES, J. L. M.; SPAROVEK, G. Köppen's climate classification map for Brazil. Meteorologische Zeitschrift, Berlin, v. 22, n. 6, p. 711-728, 2013. http://doi.org/10.1127/0941-2948/2013/0507

BONFIM-SILVA, E. M.; SILVA, T. J. A.; LUZ, V. S.; GUIMARÃES, S. L.; POLIZEL, A. P. Capim-marandu no primeiro ano de recuperação em sistemas de manejo no Cerrado. Enciclopédia Biosfera, Goiânia, v. 7, n. 12, p. 1-9, 2011.

CASTRO, M. A.; CUNHA, F. F.; LIMA, S. F.; PAIVA NETO, V. B.; LEITE, A. P.; MAGALHÃES, F. F.; CRUZ, G. H. M. Atributos físico-hídricos do solo ocupado com pastagem degradada e floresta nativa no Cerrado Sul-Mato-Grossense. Brazilian Geographical Journal, Ituiutaba, v. 3, n. 2, p. 498-512, 2012.

CIOTTA, M. N.; BAYER, C.; FONTOURA, S. M. V.; ERNANI, P. R.; ALBUQUERQUE, J. A. Matéria orgânica e aumento da capacidade de troca de cátions em solo com argila de atividade baixa sob plantio direto. Ciência Rural, Santa Maria, v. 33, n. 6, p. 1161-1164, 2003. http://doi.org/10.1590/S010384782003000600026

COMISSÃO DE FERTILIDADE DO SOLO, RS/SC (Passo Fundo, RS). Recomendações de adubação e calagem para os Estados do Rio Grande do Sul e Santa Catarina. 3. ed. Passo Fundo: Sociedade Brasileira de Ciência do Solo/Embrapa, 1995. 224p. 
CONTE, O.; WESP, C. D. L.; ANGHINONI, I.; CARVALHO, P. D. F.; LEVIEN, R.; NABINGER, C. Densidade, agregação e frações de carbono de um argissolo sob pastagem natural submetida a níveis de ofertas de forragem por longo tempo. Revista Brasileira de Ciência do Solo, Viçosa, v. 35, n. 2, p. 579-587, 2011. http://doi.org/10.1590/S0100-06832011000200027

EMBRAPA. Empresa Brasileira de Pesquisa Agropecuária. Sistema brasileiro de classificação de solos. 3. ed. Brasília: Embrapa Solos, 2013. 353p.

EUCLIDES, V. P. B.; FLORES, R.; MEDEIROS, R. N.; OLIVEIRA, M. P. Diferimento de pastos de braquiária cultivares Basilisk e Marandu, na região do Cerrado. Pesquisa Agropecuária Brasileira, Brasília, v. 42, n. 2, p. 273-280, 2007. http://doi.org/10.1590/S0100-204X2007000200017

FAVARATO, L. F.; SOUZA, J. L.; GALVÃO, J. C. C.; SOUZA, C. M.; GUARÇONI, R. C. Atributos químicos do solo sobre diferentes plantas de cobertura em sistema de plantio direto orgânico. Revista Brasileira de Agropecuária Sustentável, Viçosa, v. 5, n. 2, p. 19-28, 2015. https://doi.org/10.21206/rbas.v5i2.312

FOGEL, G. F.; MARTINKOSKI, L.; MOKOCHINSKI, F. M.; GUILHERMETTI, P. G. C.; MOREIRA, V. S. Efeitos da adubação com dejetos suínos, cama de aves e fosfato natural na recuperação de pastagens degradadas. Revista Verde de Agroecologia e Desenvolvimento Sustentável, Mossoró, v. 8, n. 5, p. 66-71, 2013.

INMET - Instituto Nacional de Meteorologia, 2018. Brazilian climatological normals 1981-2010. Available at: <http://www.inmet.gov.br/portal/>. Accessed July 22, 2019.

LANA, R. M. Q.; ASSIS, D. F.; SILVA, A. A.; GUIMARÃES, E. C.; LANA, A. M. Q.; BORGES, E. N. Alterações na produtividade e composição nutricional de uma pastagem após segundo ano de aplicação de diferentes doses de cama de frango. Bioscience Journal, Uberlândia, v. 26, n. 2, p. 249-256, 2010.

LARA, O. Q.; BONI, D.; PICHEK, D. B.; MATT, M. P.; SOUZA, C. A.; FERREIRA, E. Esterco de ave como alternativa à adubação convencional de Urochloa brizantha no estado de Rondônia (Zona da Mata). Archivos de Zootecnia, Córdoba, v. 64, n. 248, p. 355-363, 2015. http://doi.org/10.21071/az.v64i248.420

OLIVEIRA, J. G. R.; TAVARES FILHO, J.; BARBOSA, G. M. C. Alterações na física do solo com a aplicação de dejetos animais. Geographia Opportuno Tempore, Londrina, v. 2, n. 2, p. 66-80, 2016.

ORRICO JÚNIOR, M. A. P.; CENTURION, S. R.; ORRICO, A. C. A.; OLIVEIRA, A. B. M.; SUNADA, N. S. Características produtivas, morfogênicas e estruturais do capim Piatã submetido à adubação orgânica.

Ciência Rural, Santa Maria, v. 43, n. 7, p. 1238-1244, 2013. http://doi.org/10.1590/S010384782013005000085

PINTO, F. A.; SANTOS, F. L.; TERRA, F. D.; RIBEIRO, D. O.; RODRIGUES, R.; SOUSA, J.; SOUSA, E. D.; CARNEIRO, M. A. C.; PAULINO, H. B. Atributos de solo sob pastejo rotacionado em função da aplicação de cama de peru. Pesquisa Agropecuária Tropical, Goiânia, v. 42, n. 3, p. 254-262, 2012. http://doi.org/10.1590/S1983-40632012000300002

RAMOS, L. A.; LANA, R. M. Q.; KORNDÖRFER, G. H.; SILVA, A. A. Effect of organo-mineral fertilizer and poultry litter waste on sugarcane yield and some plant and soil chemical properties. African Journal of Agricultural Research, Lagos, v. 12, n. 1, p. 20-27, 2017. http://doi.org/10.5897/AJAR2016.11024

SIGNOR, D.; CZYCZA, R. V.; MILORI, D. M. B. P.; CUNHA, T. J. F.; CERRI, C. E. P. Atributos químicos e qualidade da matéria orgânica do solo em sistemas de colheita de cana-de-açúcar com e sem queima. Pesquisa Agropecuária Brasileira, Brasília, v. 51, n. 9, p. 1438-1448, 2016. http://doi.org/10.1590/s0100$204 \times 2016000900042$ 
SILVA, A. A.; COSTA, A. M.; LANA, R. M. Q.; LANA, A. M. Q. Recycling of nutrients with application of organic waste in degraded pasture. Engenharia Agrícola, Jaboticabal, v. 32, n. 2, p. 405-414, 2012. http://doi.org/10.1590/S0100-69162012000200020

SILVA, A. A.; COSTA, A. M.; LANA, R. M. Q.; LANA, A. M. Q. Teores de micronutrientes em pastagem de Urochloa decumbens fertilizada com cama de frango e fontes minerais. Bioscience Journal, Uberlândia, v. 27, n. 1, p. 32-40, 2011.

SILVA, P. P.; FERREIRA, R. S.; TEODORO, P. E.; TORRES, F. E.; ARIMA, G. M.; CAPPI, N.; RIBEIRO, L. P. Resposta de cultivares de Urochloa brizantha a doses de biofertilizantes de aves. Arquivos do Instituto Biológico, São Paulo, v. 81, n. 3, p. 286-289, 2014. http://doi.org/10.1590/1808-1657001282012

SILVEIRA JUNIOR, O.; SANTOS, A. C.; ROCHA, J. M. L.; FERREIRA, C. L. S.; OLIVEIRA, L. B. T.; RODRIGUES, M. O. D. Implantação de pastagens sob sistema monocultivo e integrado com lavoura utilizando biofertilizante de cama de aviário como adubação de cobertura. Revista Brasileira de Saúde e Produção Animal, Salvador, v. 16, n. 3, p. 499-512, 2015. http://doi.org/10.1590/S1519-99402015000300003

SYSTAT SOFTWARE. SigmaPlot for Windows Version 12.0. San Jose: Systat Software Inc., 2011.

VALADÃO, F. C. A.; MAAS, K. D. B.; WEBWE, O. L. S.; VALADÃO JÚNIOR, D. D. V.; SILVA, T. J. Variação nos atributos do solo em sistema de manejo com adição de cama de frango. Revista Brasileira Ciência do Solo, Viçosa, v. 35, n. 6, p. 2073-2082, 2011. http://doi.org/10.1590/S0100-06832011000600022 